НОВАЯ КОЛЛЕКТИВНАЯ МОНОГРАФИЯ: ЗОЛОТАЯ ОРДА В МИРОВОЙ ИСТОРИИ (КАЗАНЬ: ИНСТИТУТ ИСТОРИИ ИМ. Ш.МАРДЖАНИ АН РТ, 2016.968 С. +28 С. ЦВ. ВКЛ.)

\author{
Мари Фаверо-Думенжсу ${ }^{1,2}$ \\ ${ }^{1}$ Оксфордский университет \\ OX1 2RL, Оксфорд, Великобритания \\ ${ }^{2}$ Университет Сорбонна - Париж IV \\ 75005, Париж, Франция \\ E-mail:marie.favereau@history.ox.ac.uk
}

В период господства Золотой Орды регионы и разнородное население Центральной Азии были впервые интегрированы в единую политическую целостность. Как и большинство империй, Золотая Орда охватывала разнородные культуры. Она стала пристанищем различных религиозных общин, которые не только сосуществовали, но и работали и торговали друг с другом, что привело к беспрецедентной интенсификации взаимных обменов, особенно в Поволжье - в ее центральном районе. Золотая Орда оказала большое влияние на торговую экспансию середины XIII - середины XIV веков, и ее экономическое и политическое правление в высшей степени способствовало глобализации Старого Света.

Историки показали, как после завершения чингизидских завоеваний феноменальный торговый бум преобразовал человеческий и культурный ландшафт Евразии. Так называемый «Пушной путь» соединялся с «Шелковым путем» в Нижнем Поволжье. Здесь открывались два основных пути: восточный вел через Среднюю Азию к Китаю и Индии, а западный проходил через Крымский полуостров по направлению к миру Средиземноморья и Среднему Востоку. Золотая Орда выступала сценой для этого драматического обмена. Джучидские ханы и беки играли ведущую роль в новом международном распорядке. Не случайно, что в этот период процветания города и поселки расцвели в Поволжье, Крыму, как и на протяжении степной магистрали между Сибирью и Венгрией. С обращением кочевнической элиты в ислам дворы ханов превратились в важнейший центр исламского мира. Странствующие ученые и ремесленники из Анатолии, Средней Азии, Египта и Сирии радушно принимались в Улусе Джучи.

Политический строй Золотой Орды оказал глубокое влияние на политическую, экономическую и культурную карту современной Евразии. Исследователи показали тот уникальный способ, которым ислам объединил и социально интегрировал народы, сформировав общественную жизнь и коллективную память и соединив шаманистские практики с местным суфизмом. Истории происхождения татар и других общин Центральной Азии простираются назад, к периоду, когда ханы Берке и Узбек обратились в ислам. Многие мусульманские народы, проживающие теперь в Российской Федерации, рассматривают это время как период становления их истории. И дей- 
Фаверо-Думенжу М. Новая коллективная монография: Золотая Орда...

ствительно, исламизация является одним из важнейших элементов золотоордынского наследия.

Золотая Орда является частью общего наследия человечества. Она создала условия для роста новой утонченной культуры XIII-XIV веков в результате взаимодействия кочевнического и оседлого миров. В то время как западные академические круги только недавно стали признавать значимость этого феномена, русскоязычное научное сообщество уже давно осознало уникальность наследия Золотой Орды. Она привлекла интерес не только историков, но и археологов, искусствоведов и нумизматов Российской Федерации, особенно в Татарстане. Благодаря их работам, поднятым ими вопросам и результатам их исследований, изучение Золотой Орды стало полноценным полем научной деятельности. Западные научные круги нуждаются в более подробном знакомстве с этими научными изысканиями. С одной стороны, исторический период Золотой Орды должен быть включен в содержание учебников по истории в США, Великобритании, Франции и в Европе в целом. Мировая история должна преподаваться сквозь неевропейскую призму для достижения более глубокого подхода к нашему общему прошлому, без чего мы окажемся неспособными понять исторические корни современного глобализированного мира. С другой стороны, не менее важно, чтобы современное изучение Золотой Орды приняло во внимание историиографические дебаты и концепции, разработанные мировыми историками.

«Мир» является категорией глобальной истории, в последнее время отождествляемой историками с многозначительным понятием, выходящим за пределы более узкого понятия империи. И действительно, империи и королевства не существовали в изоляции, но зависели от более обширного мира. Задачей современной глобальной истории является определение этих миров и разъяснение их механизмов. Золотая Орда уцелела после распада Монгольской империи; она усилилась и оказала влияние на окружающий мир. Этот мир включал в себя государства-наследники Монгольской империи в Китае, Афганистане, Индии, Персии и Анатолии; как и Византию, Русь, Европу и Средний Восток. Интенсивность контактов от Средиземноморья к Каспию и далее, вплоть до Китая, иллюстрирует, насколько тесно был связан улус Джучи с более обширным миром. Поэтому история Золотой Орды не должна рассматриваться отдельно от этого глобального формообразующего феномена.

Националистские историографии склонны искажать историю в стремлении создать и распространить клише, служащие только собственным интересам. Первейшей задачей историков является дискредитировать такие неточные термины как «татарское иго», стремясь стимулировать изучение более важных вопросов: что делать с понятием общей истории, когда она выходит за границы современных наций? И каковы после этого роль и наследие Золотой Орды в мировой истории?

«Золотая Орда в мировой истории» [1] дает несколько ответов на эти важные вопросы. Она служит достижению двух целей: представить широкой академической аудитории результаты новаторских исследований, остающихся малоизвестными за пределами узкого круга специалистов, и интегрировать эти результаты в более широкую панораму мировой истории. Она комбинирует в себе различные подходы и проблемы не только для того, чтобы представить исчерпывающее отображение состояния настоящих исследований, но 
и чтобы определить наиболее перспективные направления изысканий и сделать известными наиболее результативные достижения. Это новое и всестороннее обобщение является результатом сотрудничества между ведущими исследователями из важнейших научных учреждений: Института истории им. Ш. Марджани АН РТ, Института российской истории РАН и Оксфордского университета.

Я хочу выразить мою глубочайшую благодарность тем, кто смог воплотить этот смелый издательский проект во впечатляющую и основательную коллективную монографию: Рафаэлю Хакимову, Ильнуру Миргалееву, Роману Хаутала и Вадиму Трепавлову. Благодаря невообразимой энергии наших коллег из Института истории им. Ш. Марджани Академии Наук Республики Татарстан и его Центра исследований Золотой Орды и татарских ханств, Казань показала себя (и продолжит это делать) превосходным местом для работы историков, археологов и нумизматов Золотой Орды, готовым к сопоставлению их точек зрения. Понимание мира Золотой Орды на перекрестке между Азией, Европой и Средним Востоком требует подобного диалога между исследователями с различными специализациями. Коллективные международные публикации неотъемлемы для расширения и развития комплексных областей исследований, и написание истории является коллективным начинанием, которое может извлечь неизмеримую пользу из сотрудничества между научными учреждениями, в особенности когда это сотрудничество выходит за границы одного государства. Эта международная монография предлагает читателям результаты исследований лучших специиалистов по истории Золотой Орды и знакомит с новейшими концепциями глобальной истории.

Ключевые слова: коллективная монография, средневековая история, Монгольская империя, Золотая Орда, новый вклад в изучение истории татар.

Для цитирования: Фаверо-Думенжу М. Новая коллективная монография: Золотая Орда в мировой истории (Казань: Институт истории им. Ш.Марджани АН РТ, 2016. 968 с. +28 с. цв. вкл.) // Золотоордынское обозрение. 2016. Т. 4, № 4. С. $918-$ 923. DOI: $10.22378 / 2313-6197.2016-4-4.918-923$

\section{СПИСОК ЛИТЕРАТУРЫ}

1. Золотая Орда в мировой истории. Коллективная монография / Хакимов Р.С., Фаверо М., Трепавлов В.В., Миргалеев И.М., Хаутала Р. (ред.). Казань: Институт истории им. Ш.Марджани АН РТ, 2016. 968 с. +28 с. цв. вкл.

Сведения об авторе: Мари Фаверо-Думенжу - Ph.D. (история), научный сотрудник, исторический факультет, Оксфордский университет (OX1 2RL, ул. Георгия, Оксфорд, Великобритания); университет Сорбонна - Париж IV (75005, ул. Виктор Кузин, 1, Париж, Франция). E-mail: marie.favereau@history.ox.ac.uk

Поступила 13.09.2016 г. Принята к публикации 24.11.2016 г 
Фаверо-Думенжу М. Новая коллективная монография: Золотая Орда...

\title{
NEW COLLECTIVE MONOGRAPH: \\ THE GOLDEN HORDE IN WORLD HiSTORY (KAZAN: SH.MARJANI INSTITUTE OF HISTORY OF AS RT, 2016. 968 P. + 28 P. OF COL. INS.)
}

\author{
Marie Favereau-Doumenjou ${ }^{1,2}$ \\ ${ }^{1}$ Oxford University \\ Oxford OX1 2RL, United Kingdom \\ ${ }^{2}$ La Sorbounne - Paris IV \\ Paris 75005, France \\ E-mail: marie.favereau@history.ox.ac.uk
}

During the Golden Horde's dominion, the regions and populations of central Eurasia were integrated for the first time and became politically unified. Like most empires, the Golden Horde was intrinsically cross-cultural. It accommodated diverse religious communities which not only co-habited but also worked and traded together, leading to an unprecedented intensification of the exchanges, especially in the Volga valley, its core area. The Golden Horde had a major impact on the expansion of trade in the $1250 \mathrm{~s}-1350 \mathrm{~s}$ and its economic and political regime highly contributed to the globalization of the Old World.

Historians have revealed that after the Chinggisid conquests, a phenomenal trade boom transformed the human and cultural landscape in Eurasia. The so-called "Fur Road" interconnected with the "Silk Road" at the Lower Volga Basin. Here two major routes were passable: the eastern one through Central Asia towards north India and China, and the western one through the Crimean peninsula towards the Mediterranean world and the Middle East. The Golden Horde served as the stage for this dramatic change. Jöchid khans and begs played a leading role in the new inter-regional order. It was not due to hazard that during this flourishing time, cities and villages burgeoned in the Volga Valley, in the Crimea, as well as in the steppe land corridor from Siberia to Hungary. As nomadic elites converted to Islam, the khan's court became a major hub of the Islamic world. Wandering scholars and craftsmen from Anatolia, Central Asia, Egypt and Syria were welcomed in the ulus of Jöchi.

The Golden Horde's regime had deep consequences on the political, economic and cultural map of modern Eurasia. Scholars have shown the unique way in which Islam unified and socially integrated peoples, by shaping community life and collective memory and by combining shamanist practices and local Sufism. The origin stories of the Tatars, and other Central Eurasian communities, extend back to the period when the khans Berke and Uzbek converted to Islam. Many Muslim peoples now living in the Russian Federation see it as a formative period in their history. Indeed, Islamization is one of the Golden Horde's most important legacies.

The Golden Horde is part of the common heritage of mankind. It allowed a new sophisticated culture to grow in the thirteenth and fourteenth centuries, at the hinge of the nomadic and sedentary worlds. The western academic sphere has started only recently to recognize the significance of this phenomenon while, in Russian-speaking academia, scholars have long ago understood the uniqueness of its legacy. It has raised the interest not only of historians but also of archaeologists, art historians and numismatists from the Russian Federation, and especially from Tatarstan. Thanks to their works, to the important questions they raise, and to the results of their researches, the Golden Horde studies is now a field on its own rights. Western academia needs to get better acquainted with this rich scholarship. On the one hand, the historical period of the Golden Horde should integrate history course books in US, in UK, in France and in Europe in general. World history needs to be taught through a non-European lens to get a deeper perspective on our collective past without which we cannot decipher today's globalized world. On another hand, it is also crucial that 
the current scholarship on the Golden Horde takes into account new historiographical debates and concepts developed by global historians.

A 'world' is a category of global history, recently identified by historians as a meaningful notion that goes beyond the narrower notion of empire. Indeed, empires and kingdoms did not exist in isolation, but were dependent of bigger worlds. The challenge of the new global history is to identify these worlds and to understand their mechanisms. The Golden Horde survived the fragmentation of the Mongol Empire; it grew and deeply influenced its surrounding world. This world included the successors states of the Mongol empire in China, Afghanistan, India, Persia and Anatolia as well as Byzantium, Russia, Europe and the Middle East. The density of the connections from the Mediterranean Sea to the Caspian Sea and as far as China illustrates how deeply the ulus of Jöchi was enmeshed with the wider world. Therefore, the history of the Golden Horde should not be disconnected from this world-shaping phenomenon.

Nationalist historiographies are inclined to distort history, to create and disseminate self-serving clichés. The first task of historians is to avoid inaccurate terminology such as "the Tatar Yoke", in order to encourage inquiries into more important questions: how to deal with the notion of a collective history when it crosses the borders of modern nations? What then are the role and the legacy of the Golden Horde in world history?

The Golden Horde in World History gives some answers to these important questions. It achieves a twofold aim: to bring to a larger academic audience a cutting-edge research that remains barely known outside the circle of specialists and to integrate this research into the broader perspective of world history. It combines diverse approaches and questions not only to offer an exhaustive picture of the state of the field, but also to herald the most profitable directions of research and the most fruitful advances made. This comprehensive new synthesis is the result of the collaboration of leading scholars coming from major academic institutions: Sh.Marjani Institute of History of Tatarstan Academy of Sciences, Institute of Russian History of Russian Academy of Sciences and Oxford University.

I wish to address my deepest thanks to those who turned a bold editorial project into this impressively compelling collective book: Rafael Khakimov, Ilnur Mirgaleev, Roman Hautala, Vadim Trepavlov. Thanks to the fantastic energy of our colleagues from the Sh.Marjani Institute of History of Tatarstan Academy of Sciences and its M.A.Usmanov Centre for the Golden Horde studies, Kazan proved to be and remains a wonderful venue for historians, archaeologists and numismatists working on the Golden Horde and ready to confront their views. The understanding of the Golden Horde world, at the crossroad of Asia, Europe and the Middle East, requires such a dialogue between researchers who have different expertise. International collective publications are crucial to expanding and furthering complex fields of research, and writing history is a collective undertaking that can benefit immensely from institutional collaboration - all the more so when it crosses borders. This international book will be the first to offer the readership the research outcome of the best experts in the field of the Golden Horde studies and to make the avant-garde concepts of the new global history accessible.

Keywords: collective monograph, Medieval history, Mongol Empire, Golden Horde, new contribution to the study of the history of Tatars.

For citation: Favereau-Doumenjou M. New Collective Monograph: The Golden Horde in World History. Kazan: Sh.Marjani Institute of History of AS RT, 2016. 968 p. + 28 p. of col. ins.). Golden Horde Review. 2016. Vol. 4, no. 4, pp. 918-923. DOI: 10.22378/2313-6197.2016-4-4.918-923 
Фаверо-Думенжу М. Новая коллективная монография: Золотая Орда...

\section{REFERENCES}

1. Zolotaya Orda v mirovoy istorii. Kollektivnaya monografiya. Khakimov R.S., Favero M., Trepavlov V.V., Mirgaleev I.M., Khautala R. (red.). [The Golden Horde in World History. Collective Monograph. Khakimov R.S., Favereau M., Trepavlov V.V., Mirgaleev I.M., Hautala R. (eds.)]. Kazan, Sh.Marjani Institute of History of Tatarstan Academy of Sciences Publ., 2016. 968 p. +28 p. of col. ins. (In Russin)

About the author: Marie Favereau-Doumenjou - Ph.D. (History), Research Associate, Faculty of History, Oxford University (George Str., Oxford OX1 2RL, United Kingdom); La Sorbonne - Paris IV (1, Victor Cousin Str., Paris 75005, France). E-mail: marie.favereau@history.ox.ac.uk

Received September 13, 2016 Accepted for publication November 24, 2016 